\title{
Rural Livelihood Diversification Status and Determinant Factors in Arsi, Ethiopia
}

\author{
Tamrat Gebiso Challa ${ }^{1, *}$, Ashebir Tsegaye $\mathrm{Mamo}^{2}$, Aman Nebo Tibeso ${ }^{1}$, Ibsa Dawud ${ }^{1}$ \\ ${ }^{1}$ Agricultural Economics and Agricultural Extension Directorate, Oromia Agricultural Research Institute, Asella, Ethiopia \\ ${ }^{2}$ Agricultural Engineering Directorate, Oromia Agricultural Research Institute, Asella, Ethiopia
}

Email address:

tameulove@yahoo.com (T. G. Challa)

${ }^{*}$ Corresponding author

\section{To cite this article:}

Tamrat Gebiso Challa, Ashebir Tsegaye Mamo, Aman Nebo Tibeso, Ibsa Dawud. Rural Livelihood Diversification Status and Determinant Factors in Arsi, Ethiopia. International Journal of Business and Economics Research. Vol. 8, No. 1, 2019, pp. 23-30.

doi: 10.11648/j.ijber.20190801.14

Received: December 12, 2018; Accepted: January 31, 2019; Published: March 1, 2019

\begin{abstract}
The main reason for livelihood diversification could be positive or negative factors like improving existing livelihoods, as copping strategy for changing climatic conditions landlessness due to population pressure in the rural areas. Agriculture as a sole livelihood activity in Sub-Saharan African countries in general and in Ethiopia in particular, is a failed activity due to the fact that agricultural sector in this region is highly characterized by decreasing farm sizes, low levels of output per farm, and a high degree of subsistence farming. In this research socioeconomic characteristics of the household and pattern of rural livelihoods were described and the contribution of non-farm and off-farm income sources in livelihood diversification and determinant factors were analyzed. Simpson diversification index was used to estimate the diversification status and accordingly $40 \%$ of the households were medium diversifiers and around $1 \%$ was highly diversifiers. Negative binomial regression model was used to identify determinants for number of non-farm activities and double-hurdle model was used to identify factors affecting participation and amount of earnings. Crop-livestock mixed farming is dominant activity while most farmers are involving in non-farm and off-farm income generating activities like petty trade, working on others farm, skilled handcrafting and carpenter, seasonal trading on crop and livestock etc. The main negative factors for participation were crop failure due to change in climate and shortage of farmland.Some of the pull factors which are due to seek for improved livelihood were mostly determined by educational and distance to town.
\end{abstract}

Keywords: Livelihood, Diversification, Nonfarm/off-Farm Income, Negative Binomial Model, Simpson Diversification Index, Double-Hurdle Model

\section{Background and Justification}

Diversification can be defined as the maintenance and continuous alteration of a highly-varied range of activities and occupations to minimize household income variability, reduce the adverse impacts of seasonality, and provide employment or additional income [1-5]. In most African and Asian countries rural farmers do not specialize on crop production, livestock production or fishing and rather they diversify their income sources and tried to use all possible options of activity portfolios. The term livelihood diversification refers to a key strategy taking place at different levels of the economy, which are usually directly related and linked to each other [6]. The livelihood may be considered as a strategy for coping or risk management for farm households [7-10]. Some also defined farm household diversification as income strategies of rural individuals or households in which they expand their number of activities, regardless of the location or sector [11-12]. Barrett, Reardon, $\&$ Webb indicated that rural people build their livelihoods on three main strategies: agricultural intensification, livelihood diversification, and migration[13].

The main reason for livelihood diversification could be positive or negative factors like improving existing 
livelihoods, as copping strategy for changing climatic conditions landlessness due to population pressure in the rural areas. Due to this in most African and Asian countries, including Ethiopia, migration from rural to urban areas was considered as livelihood diversification strategy [14].

Different scholars classified livelihoods in rural areas based on different factors. For instance, [15] identified about four strategies. The first group was termed as "full time farmers" where their entire livelihood is totally dependent on agricultural production. The second group was those who produce on their on-farm and get additional income by being employed on others farm as waged laborer the authors called them as "farmers and farmer workers". The third strategy was combination of farm and non-farm income sources. The fourth and last strategy was combination of all above discussed strategies farming (both crop and livestock), employment on others farm, non-farm activities like trading livestock and crop, commerce, salaried employment etc.

According to different authors there are two types of factors that enable farm households to engage into different livelihood diversification activities. These factors can be termed as push factor and pull factors. In situations of highrisk agriculture and poverty, poorer small-holders without the necessary assets may be pushed to seek alternative incomes by engaging in low-return and sometimes risky nonfarm activities [15]. On the other hand, it is mainly among richer households or in regions with favorable agricultural conditions that livelihood diversification driven by motives to raise incomes or accumulate wealth prevails [11, 16-17]. Diversification is therefore associated with both livelihood survival and distress under deteriorating conditions, as well as with livelihood enhancement under improving economic conditions [18].

In general livelihood diversification is a dynamic process in which peoples combine different activities to meet their various needs at different times mainly to sustain their food security [19-20]. To capitalize on activities that are more suitable and preferred by peoples due to their existing situation for policy and development intervention, identification of socioeconomic characteristics, dominant patterns of rural livelihoods and contribution of non-farm and off-farm income sources in rural livelihood diversification should be studied. Moreover, studies by different scholars and development practitioners indicated that agriculture as a sole livelihood activity in Sub-Saharan countries is a failed activity [21] due to the fact that agricultural sector in this region is highly characterized by decreasing farm sizes, low levels of output per farm, and a high degree of subsistence farming [22]. These lead the farming community to diversify their livelihood on both farming and non-farm activities.

Therefore, in this research socioeconomic characteristics of the household and pattern of rural livelihoods were described and the contribution of non-farm and off-farm income sources in livelihood diversification and determinant factors were analyzed

\section{Research Methodology}

\subsection{Study Area Description, Sampling Method and Sample Size}

This research was conducted in Arsi zone Oromia regional state of Ethiopia. The zone is known for it good potential of production especially know as "wheat-belt of the country, Ethiopia". The zone is endowed with diversified agroecologies that enabled it to produce different crop and livestock products. Seven representative districts were selected (sampled) purposively based on representativeness to different agro-ecologies, production systems and infrastructural development. From each district two or one PAs were selected and from each PAs thirty two respondent farmers were selected and interviewed using structured questionnaire. FGD was also conducted.

\subsection{Data Analysis Methods}

To describe the socioeconomic characteristics of households, descriptive statistics like meanwere employed and for identification of the dominant patterns of rural livelihoods or to measure the diversification of livelihoods, Simpson Index measurement method was used.

$$
S D I=1-\sum_{i=1}^{n} P_{i}^{2}
$$

Where;

SDI=Simpson Diversification Index

$\mathrm{n}=$ total number of income sources and

$\mathrm{Pi}=$ Income proportion of the $\mathrm{i}$-th income source

Khatun and Roy [23]Indicated that SDI is simple, robust and widely applicable and widely employed method used to measure livelihood diversification. The SDI value runs from 1 to 0 and as the income from each source tends to uniform, the SDI will be nearer to 1 and high variation in income sources uniformity approaches to zero[24]; and the diversification status of the households was classified based on the rating given by previous authors as low (0 to 0.38$)$, medium $(0.39$ to 0.63$)$ and high (above 0.63).

For the identification of determinants of household non/off-farm income participation, different authors used different econometric models. The dependent variable in our case (measured in terms of number of non/off-farm activities that the household engaged in) is a discrete count data. Therefore, the possible standard models can be used are Poisson and negative binomial regression to be selected based on the nature of the count-data. According to Cameron and Trivedi[25], Poisson is a widely used model for analysis of discrete count data and some authors ([26-27]) used for analysis of determinants of non-farm income.

But the Poisson model has strong assumption of Equi- 
disperson (i.e. the conditional variance of the dependent variable is equal to the conditional mean $[25,28]$ whereas, in most count data this assumption cannot be fulfilled due to high positive skeweness of the dependent variable because of the existence of many zeros in the data where many respondents reported zero number of non/off-farm income source activities participation. Therefore, a model which has an assumption of less restriction on the necessity equality of variance and the mean [28] is more preferable. The negative binomial model (NBM) modifies the Poisson model to address over-dispersion by including a disturbance/error term to the Poisson model. Accordingly this model negative binomial model (NBM) was employed in this research.

\section{Result and Discussion}

\subsection{Socioeconomic Characteristics and Resource Ownership of Households}

Around 53 and 45 percent of the sampled households were Muslims and Orthodox Christianity followers respectively. Around 94 percent of the household was male headed and the rest 6 percent was female headed. The mean age of the household head was around 45 years (good working age) while they have mean educational year of 5.28 years. Household's spouse educational status was found to be lower than that of household head which was 2.8 years of education. On average there was one family member which is not educated. There were 6.26 family members per a household on average with standard deviation of 2.26.

Table 1. Socioeconomic profile of sample farm households in Arsi zone.

\begin{tabular}{llllll}
\hline No. & Variable & Minimum & Maximum & Mean value & Std. Deviation \\
\hline 1. & Total Family size & 1 & 14 & 6.26 & 2.26 \\
2. & Male family size & 0 & 9 & 3.45 & 1.68 \\
3. & Female family size & 0 & 7 & 2.81 & 1.50 \\
4. & House number & 1 & 1.3 & 2.70 & 1.66 \\
5. & Adult man-equivalent & 0.8 & 7.90 & 3.28 & 1.41 \\
6. & Livestock (TLU) & 0 & 14.69 & 7.54 & 1.84 \\
\hline
\end{tabular}

Majority of the household $(40.67 \%)$ have land size between 1 and 2 hectare while only around 3 percent have landholding of above five hectares. In general more than $75 \%$ of the households have landholdings of less or equal to two hectares only (Table 2). The mean landholding of households was 2.39 ha with mean cultivated land size of $2.33 \mathrm{ha}$. The land use pattern shows that land allocated for crop production accounts for large proportion followed by grazing land and residential land with mean of $1.8 \mathrm{ha}, 0.28 \mathrm{ha}$ and $0.18 \mathrm{ha}$ respectively. Mean livestock possession was 7.54 TLU and mean ofthe number of houses a household possessed was 2.7 (table 3).

Table 2. Landholding Distribution by Household percent in Arsi zone.

\begin{tabular}{llll}
\hline Range of landholding & Percent of holders & Std. Deviation & Cumulative Average \\
\hline 1. Less than 0.5 hectare & 9.83 & 7.2 & 9.83 \\
2. Between 0.5ha and 1ha & 25.4 & 13.65 & 35.23 \\
3. Between 1ha and 2ha & 40.67 & 23.17 & 75.9 \\
4. Between 2ha to 5ha & 20.9 & 16.72 & 96.8 \\
5. Above 5ha & 3.2 & 3.52 & 100 \\
\hline
\end{tabular}

Source: Districts office of agriculture and natural resources development

The result revealed that there was considerable land allocation for forest and grazing while the degraded (land of no use) is also significant which is because of soil degradation due to miss-use of the land. From both FGD and household level survey result, there is no communal grazing land except in pastoral and agro-pastoral areas of Merti district (Table 4).

Table 3. Own land use pattern of household.

\begin{tabular}{llll}
\hline No. & Land use & Mean value (ha) & Std. Deviation of mean \\
\hline 1. & Rain fed crop production & 1.77 & 1.4 \\
2. & Grazing land & 0.28 & 0.49 \\
3. & Residential land & 0.18 & 0.17 \\
4. & Forest land & 0.07 & 0.22 \\
5. & Irrigated crop production & 0.04 & 0.14 \\
6. & Degraded land & 0.03 & 0.11 \\
7. & Others & 0.01 & 0.04 \\
8. & Total landholding & 2.39 & 1.80 \\
\hline
\end{tabular}

Source: own household survey 
Table 4. Mean Income and their Sources Distribution across Farming system in Arsi Zone.

\begin{tabular}{lllllllll}
\hline Farming system cluster & \multicolumn{1}{l}{} & $\mathbf{2}$ & $\mathbf{3}$ & $\mathbf{4}$ & $\mathbf{5}$ & $\mathbf{6}$ & $\mathbf{7}$ & total \\
\hline Variables & $\mathbf{1}$ & $\mathbf{2}$ & 14 & 46 & 18 & 35 & 12 & 12 \\
\hline $\mathrm{N}$ & 53 & 5.50 & 6.00 & 7.17 & 6.71 & 6.08 & 6.50 & 6.26 \\
Total Family size & 6.06 & 2.57 & 3.67 & 4.05 & 3.51 & 3.33 & 2.91 & 3.45 \\
Male family size & 3.45 & 2.93 & 2.41 & 3.11 & 3.20 & 2.75 & 3.58 & 2.81 \\
Female family size & 2.60 & 3.46 & 2.43 & 2.22 & 2.63 & 3.08 & 1.83 & 2.69 \\
House number & 3.06 & 2.80 & 3.48 & 3.50 & 3.30 & 3.22 & 2.85 & 3.28 \\
Adult man-equivalent & 3.32 & 7.55 & 7.20 & 6.66 & 6.36 & 6.53 & 5.43 & 7.54 \\
Livestock (TLU) & 9.62 & 3.17 & 1.54 & 2.80 & 2.04 & 2.48 & 2.74 & 2.39 \\
Total land holding & 2.89 & 2.85 & 1.60 & 2.38 & 2.18 & 1.60 & 2.22 & 2.33 \\
Total cultivated land & 3.20 & 2.85 & & & &
\end{tabular}

Source: own survey and focus group discussion (FGD) result

Key: 1=mechanized wheat belt; 2=highland barley belt; 3=non-mechanized wheat-tef belt; 4=lowland maize-sorghum belt; 5=pastoral/agro-pastoral; $6=$ irrigation based farming; $7=$ coffee-chat tree based farming

\subsection{Households Off-Farm Activities and Food Security Status}

Household's off-farm income sources could be both farm and non-farm activities. When a household member works on other's farm activity to earn additional income as a paid laborer during his off-time, it will be farm activity worked as off-farm activity. But when the household member works on non-farm activities like petty trade, skilled labor as carpenter, salaried worker as guard e.t.c., it will be non-farm off-farm income source activity.

Accordingly, around 32 percent of the total respondent households have participated on different off-farm activities because of different reasons like seeking additional income $(17.4 \%)$, inadequate farmland (10\%) and fear of crop failures $(5 \%)$.The major types of non-farm/off-farm activities in which the respondents participated were petty trades, crop and livestock trading, laborer on others' farm, carpenter works, civil servant, renting house in small towns, serving as broker in nearby markets, making alcohol drinks (tela/local beer and areke) and others.

Food security status of the household was assessed through simple interview by asking whether the household is food secured throughout the year or not. Accordingly, around 52\% of total respondents answered that they were food unsecured and were not producing enough food for their family consumption. Furthermore, it was observed that there were food aid program in each sample districts. For instance the information from Chole district revealed that around $50 \%$ of the households in the district were food unsecured and under aid program (table 5).

Table 5. Reasons for Participation on off-farm activities and food security Status.

\begin{tabular}{lll}
\hline No. & Description & Response (percent of "Yes" answer) \\
\hline 1 & Seeking additional income & $17.40 \%$ \\
2 & Inadequate farmland & $10.00 \%$ \\
3 & Fear of crop failures & $5 \%$ \\
4 & The HH is food secured & $48 \%$ \\
5 & The HH is not food secured & $52 \%$ \\
\hline
\end{tabular}

Source: own survey result

\subsection{Livelihood Diversification Status in Arsi Zone, Oromia Regional State}

Even though the term income diversification is mostly used in connection with livelihood diversification for ease of analysis and interpretation,Ellis [8] makes a distinction between the two and defines income diversification as "the composition of household income at a given point in time while livelihood diversification is considered as an active social process involving engagement in increasingly complex portfolio of activities overtime". Diversification can be measured using three approaches: assets measure approach, activities measure approach and incomes measure approach [13].

According to Zerihun B. Weldegebriel[29], the use of assets and activities to measure are difficult. In African context asset valuation is difficult due to the lack of secondary asset markets and variability of returns to assets because of asset fixity. Activities on the other hand, despite being useful in identifying diversification choices, are difficult to value and lack direct theoretical relevance.

Therefore, in this research income measurement approach was followed to describe and indicate the livelihood diversification of the study area. Different authors used different approach of livelihood diversification. The classification was farm, off-farm and non-farm[8].According to this author farm income source include income earned from crop and livestock production, including own consumption and sales. Off-farm income mainly refers to wage or exchange of labour in cash or in-kind away from one's own land within agriculture. It also includes some selfemployment in natural resource extraction activities. Onfarm income includes the following non-agricultural income sources like rural non-farm wage employment, selfemployment (own business), property income (from rents) and remittances and transfers. Barrett et al. [13] and Zerihun B. Weldegebriel[29] also adopted theEllis approach[8].

In this piece of research work the different income sources were broadly classified in to three categories as crop production, livestock production and non/off-farm activities. Non-farm and off-farm income sources were considered together because both of them are practiced by farming 
community during farming or off-farming seasons. Farm activity was categorized in to crop and livestock production as the potential for two sectors are different for different districts since the survey comprises all agro-ecologies of the zone.

Table 6. Simpson Diversification Index (SDI).

\begin{tabular}{lll}
\hline SDI value & Percent of household & Level of Diversification \\
\hline 0 to 0.38 & $59.47 \%$ & Less diversified \\
0.39 to 0.63 & $40.00 \%$ & Medium \\
Above 0.63 & $0.53 \%$ & highly diversified \\
\hline
\end{tabular}

To quantify the diversification status of the livelihoods
(income),Simpson diversity index (SDI) was employed. As it is mentioned under analysis method of this document, the SDI value runs from zero to one and zero implies complete specialization while value of SDI one implies complete diversification. According to the result of this research around $29 \%$ of the respondents have SDI value of zero and are completely specialized. In general $59.47 \%$ of the respondents have SDI values of 0 to 0.38 and have less diversification in income sources. Around $40 \%$ of the respondents have SDI values of 0.39 to 0.63 and were categorized as medium diversifiers and only $0.53 \%$ was considered as high diversifiers (table 6).

Table 7. Non/off-farm Income participation of the respondents in Arsi zone.

\begin{tabular}{llll}
\hline Number of income sources & no. of participant & percent & cumulative percent \\
\hline No off/non-farm income sources & 130 & 68.4 & 68.4 \\
One off/non-farm income source & 44 & 23.2 & 91.6 \\
Two off/non-farm income sources & 12 & 6.3 & 97.9 \\
Three off/non-farm income sources & 1 & 0.5 & 98.4 \\
Four off/non-farm income sources & 3 & 1.6 & 100 \\
\hline
\end{tabular}

Source: own computation from survey result

According to table 7 above around $33 \%$ of the respondents participate on different non/off-farm income generating sources off which more than $8 \%$ were participating on more than one activities. Farmers are generally classified as model, medium and resource poor in the community based on their resource endowment and participation status in the community. Wealth and participation status of the farmer in the community has also great impact on participation on non/off-farm income source activities and the return from the activities. Table 8 below also revealed that the amount and diversification of sources for households in non/off-farm income sources are high for model farmers.

Table 8. ANOVA for wealth status and non/off-farm Income Diversification.

\begin{tabular}{|c|c|c|c|c|c|}
\hline SDI & Wealth Status & $\mathbf{N}$ & Mean value & F-value & Sig. \\
\hline \multirow{11}{*}{ Non-farm income } & Model & 44 & $0.36(0.21)^{\mathrm{a}}$ & 8.36 & 0.000 \\
\hline & Medium & 122 & $0.21(0.22)$ & \multirow{3}{*}{$0.20(0.22)$} & \\
\hline & Resource poor & $\mathrm{s}$ & 24 & & \\
\hline & Total & 190 & $0.24(0.22)$ & & \multirow{3}{*}{0.014} \\
\hline & Model & 44 & $10135.5(12554.12)$ & \multirow[t]{3}{*}{4.39} & \\
\hline & Medium & 122 & $5450.17(10185.55)$ & & \\
\hline & Total & 190 & $6256.22(106636.57)$ & & \multirow{5}{*}{0.015} \\
\hline & Model & 44 & $0.73(0.95)$ & \multirow[t]{4}{*}{4.30} & \\
\hline & Medium & 122 & $0.34(0.64)$ & & \\
\hline & Resource poor & 24 & $0.42(0.93)$ & & \\
\hline & Total & 190 & $0.44(0.77)$ & & \\
\hline
\end{tabular}

${ }^{\mathrm{a}}$ Values in parenthesis are standard deviation

\subsection{Determinants of Non-farm Activity Participation}

Table 9 shows the result of negative binomial regression model (NBM). Three demographic variables which are household age, household head gender and household education were found to be significant. Age positively affects income diversification which is significant at $5 \%$ probability level. The increase in age by a year increases diversification by probability of $13 \%$ while the increase in year of education by one year increases the income diversification by around $7.5 \%$. Being male has negative impact on income source diversification by around $59 \%$ (significant at $10 \%$ ). Socioeconomic variables landholding and household's market distance were significantly and negatively affecting variables with probability level of 5 and $1 \%$ respectively. Cultivated land size has positive significant effect on income source diversification and the increase in size of land under cultivation increases the probability of diversification by $11.3 \%$ at $1 \%$ probability level. This is may be due to most land owners are not using their lands and rent out to landless and landless are participating on both farm and non-farm activities. 
Table 9. Determinants of non-farm activity diversification in rural Arsi Zone, Ethiopia.

\begin{tabular}{llll}
\hline Negative binomial regression & Number of obs $=$ & $\mathbf{1 8 8}$ & \\
\hline & LR chi2(13) $=$ & $\mathbf{2 8 . 1 8}$ & $\mathbf{0 . 0 0 8 5}$ \\
\hline Dispersion $=$ mean & Prob> chi2 $=$ & $\mathbf{0 . 0 5 4 1}$ & $\mathbf{Z}$ \\
\hline Log likelihood $=\mathbf{- 2 4 6 . 4 4}$ & Pseudo R2 $=$ & & $1.95^{* *}$ \\
\hline Dependent Variable & & $\mathbf{d y} / \mathbf{d x}$ & $-1.91^{*}$ \\
\hline Number of Non-Farm Income Activities & Coefficient & .013 & $3.34^{* * *}$ \\
\hline HHHAGE & $0.01(0.01)$ & -.587 & 0.97 \\
HHHSEX (dummy Male=1) & $-0.49(0.25)$ & .075 & -1.04 \\
HHHEDUC & $.08(0.02)$ & .064 & -0.61 \\
FAMLYSIZE & $0.08(0.08)$ & -.708 & -0.62 \\
DEPENDENCYRATIO & $-0.74(0.71)$ & -.061 & $2.01^{* * * *}$ \\
MANEQUIVALENT & $-0.09(.15)$ & -.005 & $-1.85^{* *}$ \\
TLU & $-.01(0.01)$ & .113 & -0.90 \\
CULTIVATELAND & $0.11(0.06)$ & -.127 & $2.11^{* * * *}$ \\
LANDHOLDING & $-0.13(0.07)$ & -.138 & -0.48 \\
CREDITACCESS (1=yes) & $-0.12(0.13)$ & .007 & -.073 \\
MARKETDISTANCE $(1=y e s)$ & $-0.02(0.01)$ & -0.71 & \\
ELECTRICITYACCESS (1=yes) & $-0.08(.16)$ & & \\
CONSTANT & $-0.33(.47)$ & & \\
\hline
\end{tabular}

Source: own survey result

Table 10 below presents the results of the double-hurdle model. The coefficients in the first hurdle indicate how a given variable affects the likelihood (probability) to participate in non-farm income generating activity. The second hurdle presents the variables that influence the level/intensity of non-farm income diversification, given that a decision is made to participate in non-farm activities.

Table 10. Determinants of Non-farm Income Participation and Earnings (double hurdle result).

\begin{tabular}{|c|c|c|c|c|}
\hline & & & Number of obs $=188$ & \\
\hline & & & Wald chi2(13) $=19.19$ & \\
\hline \multirow[t]{3}{*}{ Log likelihood=-249.82 } & & & Prob $>$ chi $2=0.1172$ & \\
\hline & (First Hurdle) & & (Second Hurdle) & \\
\hline & COEFFICIENT & $\mathbf{Z}$ & COEFFICIENT & $\mathbf{Z}$ \\
\hline TLU & $-0.01(0.01)^{\mathrm{a}}$ & -0.86 & $-0.01(0.01)$ & -0.52 \\
\hline CULTLAND & $0.02(0.09)$ & -0.23 & $0.15(0.07)$ & $2.27 * * *$ \\
\hline LANDHOLDING & $-0.02(0.10)$ & -0.17 & $0.15(0.08)$ & -1.95 \\
\hline HHHEDUC & $0.10(0.03)$ & $3.36^{* * *}$ & $0.02(0.03)$ & $2.74 * * *$ \\
\hline HHHAGE & $0.02(0.01)$ & $2.12 * *$ & $0.01(0.01)$ & 0.84 \\
\hline HHHSEX & $-0.56(0.45)$ & $-1.92 *$ & $-0.44(0.33)$ & $-1.92 *$ \\
\hline FAMLYSIZE & $0.11(0.10)$ & 1.12 & $0.03(0.11)$ & 0.25 \\
\hline DEPRATIO & $-0.89(0.90)$ & -0.99 & $-0.12(0.90)$ & -0.13 \\
\hline MANEQUI & $0.14(0.19)$ & -0.73 & $0.05(0.19)$ & 0.26 \\
\hline CREDIT & $0.12(0.16)$ & -0.74 & & \\
\hline MMKTDIST & $.02(0.02)$ & $-2.18 * *$ & & \\
\hline ELECTRIC & $0.19(0.23)$ & 0.80 & & \\
\hline CROPINCOME & & & $4.44(1.33)$ & $3.33 * * *$ \\
\hline CONS & $0.23(0.67)$ & -0.34 & $1.26(0.59)$ & $2.14 * *$ \\
\hline
\end{tabular}

${ }^{a}$ Number in parentheses are standard deviation

Accordingly, probability of participating in non-farm income was positively and significantly affected by household educational background and household age while it was negatively and significantly affected by household gender (being female has negative effect on participation), and distance from market center. Similarly, the amount of income gained from non-farm income was affected by different variables. Size of cultivated land, household head educational background and income amount gained from crop cultivation were variables that affect amount of income from non-farm income sources positively and significantly. Similar to participation probability, amount of income from non-farm income source was significantly affected by household hold gender negatively.

\section{Conclusion and Recommendations}

More than half of the total households $(52 \%)$ were food 
insecure while only around 32 percent of the respondents have at least one or more non-farm income sources. The main reasons for participation on non-farm income were inadequate farmland and seeking additional income. There demographic variables which are household age, household head gender and household education affect the number of non-farm a household participated in. Age positively affects income diversification which is significant at $5 \%$ probability level.

Households which have relatively economic betterment than others also good participation opportunities due to good income amount which enables them start simple businesses like grain and livestock trading. The other main reason for livelihood diversification was landlessness which is a push factor. Urbanization (being resident of urban or peri-urban which was explained in terms of its proxy variable, distance to nearby market) was also one of the most important factors to diversify livelihood by participating in non/off-farm activities. Households having diversified income sources are in general those having better educational background and others are who have better farm income while those who are in the middle are not diversifiers.

In general livelihood diversification is a crucial activity that should be promoted by government bodies since per capita landholding is decreasing through time because of population pressure. Therefore, increasing access to main roads, electricity and training on business development and management should be the future intervention plan by development practitioners to alleviate the increasing food insecurity in the area by providing livelihoods options.

\section{References}

[1] Ellis, F. (2000). The Determinants of Rural Livelihood Diversification in Developing Countries. Journal of Agricultural Economics, 51, 289-

302. http://dx.doi.org/10.1111/j.1477-9552.2000.tb01229.x.

[2] Barrett, C. B., Reardon, T., \& Webb, P. (2001a). Nonfarm income diversification and household livelihood strategies in rural Africa: Concepts, dynamics, and policy implications. Food Policy, 26, 315-331. doi:10.1016/S03069192(01)00014-8.

[3] Lanjouw, J. O., and Lanjouw, P. (2001). The rural non - farm sector: issues and evidence from developing countries. Agricultural Economics, 26(1), 1-23.

[4] Davis, J. R., \& Bezemer, D. (2004). The development of the rural non-farm economy in developing countries and transition economies: key emerging and conceptual issues. Available at SSRN 693061.

[5] Haggblade, S., Hazell, P., and Reardon, T. (2010). The Rural Non-farm Economy: Prospects for Growth and Poverty Reduction. World Development, 38(10), 1429-1441. doi:10.1016/j.worlddev.2009.06.008.

[6] Start, D. (2001). The rise and fall of the rural non-farm economy: Poverty impacts and policy options. Development Policy Review, 19, 491-505. doi:10.1111/1467-7679.00147.
[7] Dercon, S. (2002). Income risk, coping strategies, and safety nets. The World Bank Research Observer, 17, 141-166. Retrieved

from https://www.jstor.org/stable/3986329https://doi.org/10.1093/w bro/17.2.141.

[8] Ellis, F. (1998).Household strategies and rural livelihood diversification. Journal of Development Studies, 35, 1-38. doi:10.1080/00220389808422553.

[9] Reardon, T., Delgado, C., \& Matlon, P. (1992).Determinants and effects of income diversification amongst farm households in Burkina Faso. Journal of Development Studies, 28, 264-296. doi:10.1080/00220389208422232.

[10] Start, D., \& Johnson, C. (2004). Livelihood options?: The political economy of access, opportunity and diversification. London: Overseas Development Institute.

[11] Loison, S. A., \&Loison, S. A. (2016). Rural livelihood diversification in Sub-Saharan Africa: A literature review. The Journal of Development Studies, 51, 1125-1138. doi:10.1080/00220388.2015.1046445.

[12] Saha, B., \& Bahal, R. (2012).Constraints impeding livelihood diversification of farmers in West Bengal. Indian Research Journal of Extension Education, 12, 59-63.

[13] Barrett, C.B., Reardon,T., and Webb, P. (2001b). Nonfarm income diversification and household livelihood strategies in rural Africa: concepts, dynamics, and policy implications. Food Policy, 26(4), 315-331. doi:10.1016/S03069192(01)00014-8.

[14] McDowell, C. and A. de Haan (1997) Migration and Sustainable Livelihoods: A critical review ofthe literature. IDS mimeo.

[15] Christopher B. Barrett, Mesfin Bezuneh, and Abdillahi Aboud (2001). Income diversification, poverty traps and policy shocks in Co^te d'Ivoire and Kenya.

[16] Steven Haggblade Peter Hazell and Thomas Reardon (2010). The Rural Non-Farm Economy: Prospects for Growth and Poverty Reduction. World Development Vol. 38, No. 10, pp. 1429-1441, 2010. doi:10.1016/j.worlddev.2009.06.008.

[17] Makita, R. (2016). Livelihood diversification with certification supported farming: The case of land reform beneficiaries in the Philippines. Asia Pacific Viewpoint, 57, 44-59. doi:10.1111/apv.12106.

[18] Anke Niehof. 2004. The significance of diversification for rural livelihood systems. Food Policy 29 (2004) 321-338. doi:10.1016/j.foodpol.2004.07.009. Available online at www.sciencedirect.com.

[19] DFID (Department for international development). 2009. Sustainable livelihoods Guidance sheet, Brighton.

[20] Penney, A. 2008.Identification of a livelihood strategy and programme to address underlying causes of food insecurity in Somalia, final report to European Union and GRUPPO SOGES, Turin.

[21] Babatunde RO (2013). On-Farm and Off-farm Works: Complement or Substitute? Evidence from Rural Nigeria. Contributed paper for the 4th International Conference of the African Association of Agricultural Economists, September 22-25, 2013, Hammamet, Tunisia. URL: http://ageconsearch.umn.edu. Accessed on June 10, 2014. 
[22] Jirstrom M, Andersson A, Djurfeldt G (2011). Smallholders caught in poverty-flickering signs of agricultural dynamism. In African Smallholders: food crops, markets and policy. (edsDjurfeldt et al.) London: CABI. Chapter, 4:74-106.

[23] Khatun, D., and B.C. Roy. 2012. Rural livelihood diversification in West Bengal: Determinants and constraints. Agricultural Economics Research Review 25(No.1): 115-124.

[24] Sahal, B., and R. Baha. 2010. Livelihood diversification pursued by farmers in West Bengal. Indian Research Journal of Extension Education 10 (2): 2.

[25] Cameron, A. C., and Trivedi, P. K. (2010). Micro econometrics using Stata, Revised Edition. Stata Press.
[26] Olivia,S., and Gibson,J. (2008).The Effect of Infrastructure Access and Quality on Non-farm Employment and Income in Rural Indonesia. Presented at the 2009 Conference, August1622, 2009, Beijing, China, International Association of Agricultural Economists.

[27] Senadza,B.(2012).Non-

farmIncomeDiversificationinRuralGhana:Patternsand

Determinants. African Development Review, 24(3), 233-244.

[28] Greene,W.(2008).Functionalformsforthenegativebinomialmod elforcountdata. Economics Letters, 99(3), 585-590.

[29] Zerihun B. Weldegebriel (nd). Rural Non-Farm Diversification in Ethiopia: What Determines Participation and Returns? 